\title{
EFFECT OF DIFFERENT LEVELS OF ZINC ON GROWTH PERFORMANCE AND GONADOSOMATIC INDEX OF NILE TILAPIA (OREOCHROMIS NILOTICUS) FEMALES
}

\author{
AHMED MOSTAFA KHATER
}

Central Lab. for Aquaculture Research Abbassa, ARC, Giza

(Manuscript received 11 September 2007)

\section{Abstract}

The present experiment was conducted at the Central Laboratory for Aquaculture research in order to investigate the optimum growth performance, survival rate and gonadosomatic index of (Oreochromis niloticus) females reared in glass aquaria as affected with different levels of zinc.

The experimental system consisted of 18 experimental glass aquaria $(80 \times 40 \times 50 \mathrm{~cm})$. Each aquarium was stocked with 10 of ( $O$. niloticus) females, which fed diets with different levels of zinc $0.0,10,25,50,75$ and $100 \mathrm{mg} / \mathrm{kg}$ diet, respectively.

The results indicated that there were significant differences in growth performance among zinc levels feed. The averages of final body weight, weight gain and daily weight gain showed that the highest results were obtained from the level $25 \mathrm{mg} \mathrm{Zn/} \mathrm{kg} \mathrm{diets}$ followed in a decreasing order by $50,75,100$ and $0.0 \mathrm{mg} \mathrm{Zn}$ (the control) levels.

The survival rate at $25 \mathrm{mg} \mathrm{Zn} \mathrm{/} \mathrm{kg}$ diets was the highest results than other treatments.

The highest value of gonadosomatic index (2.14) was obtained from level of $50 \mathrm{mg} \mathrm{Zn} \mathrm{/} \mathrm{kg}$ diets than other treatments:

The present results found that the optimal growth performance, survival rate and gonadosomatic index of (Oreochromis niloticus)' females fingerlings was obtained from level of $25 \mathrm{mg} \mathrm{Zn/} \mathrm{kg} \mathrm{diets.}$

\section{INTRODUCTION}

Zinc is an essential element for living organisms, being an indispensable cofactor for the normal activity of many enzymes, such as DNA and RNA polymerases, which act in protein synthesis (Hayashi et al. (2001)). While severe zinc deficiency causes growth impairment and anorexia. A marginal zinc deficiency causes depression of the immune response (Cousins. 1996) and it was found that zinc is essential for normal growth, reproduction, and wound healing (Stahl et al. 1989a). More than 200 different enzymes require zinc for maximum catalytic activity, including carbonic anhydrase, alkaline phosphatase, alcohol dehydrogenase, acid phosphatase, lactic dehydrogenase, carboxypeptidase, and superoxide dismutase (Thompson et al. 1989).

Zinc is an essential micronutrient that plays a crucial role in many cellular processes involving transcription, enzyme structure and activity. Protein interactions 
and even cell signaling (Vallee and Falchuk, 1993). Zinc is involved in antioxidant defense (Bray and Bettger, 1990) and in maintaining membrane integrity (Bettger and O. Dell, 1981). However, zinc may become toxic if accumulated at high levels and many proteins are therefore involved in zinc homeostasis (Hogstrand and Wood, 1996).

The dietary zinc requirement has been determined for several fish species. The requirement values reported were 15 to $30 \mathrm{mg} \mathrm{Zn} / \mathrm{kg}$ diets for rainbow trout and common carp (Ogina and Yang, 1978) and $20 \mathrm{mg} \mathrm{Zn} \mathrm{/} \mathrm{kg} \mathrm{diets} \mathrm{for} \mathrm{Channel} \mathrm{catfish}$ (Gatlin and Wilson, 1983), Blue tilapia (Oreochromis aureuse) which require $20 \mathrm{mg}$ zinc / kg diet (McClain and Gatlin, 1988) and for Nile tilapia was $30 \mathrm{mg}$ zinc/kg purified diet for maximum weight gain and suitable zinc levels in bones and blood (Eid and Ghonim, 1994).

Zinc uptake is significantly correlated to increasing GSI (Thompson, et al., 2002). The aim of this work is to investigate the optimum growth performance, survival rate and gonadosomatic index of Oreochromis niloticus females reared in glass aquaria affected by different levels of zinc.

\section{MATERIALS AND METHODS}

The present experiment was conducted at the Central Laboratory for Aquaculture Research, to investigate the optimum growth performance, survival rate and gonadosomatic index of (Oreochromis niloticus) females fingerlings reared in glass aquaria affected by different dietary levels of zinc.

The experimental system consisted of 18 experimental glass aquaria $(80 \times 40 \times 50 \mathrm{~cm})$. Each aquarium was stocked with 10 (O. niloticus) females with an average initial weight ranging from 25.30 to $29.9 \mathrm{gm}$.

A total number of 180 Oreochromis niloticus females were used in this experiment. Oreochromis niloticus females were stocked in glass aquaria and fed on the experimental diets containing different levels of zinc as follow $(0.0,10,25,50$, 75 and $100 \mathrm{mg} / \mathrm{kg}$ feed). Each treatment was represented in three replicate.

The Oreochromis niloticus females were fed on diet containing of $25.23 \%$ protein twice / daily. The ingredients of the diet were $28.5 \%$ egg white, $38.5 \%$ starch, $8 \%$ mixture of oils, $20 \%$ cellulose, $2 \%$ zinc free mineral mixture, $2 \%$ vitamin and $1 \%$ CMC (carboxy methyl cellulose). The ingredient and the proximate analyses of the diet are illustrated in Table (1).

Each aquarium was supplied with compressed air via an air-stone from air pumps (Boss 9500 . Germany). Well-aerated water supply was provided from a storage fiberglass tank. Water level in each glass aquarium was kept at $40 \mathrm{~cm}$ depth. 
All aquaria were drained and cleaned every day during experimental period. Water temperature and dissolved oxygen concentration were measured by using YSI model 58-oxygen meter (Yellow Springs Instrument, Yellow Springs, OH. USA). Total ammonia and nitrite were measured once weekly using a DREL. 2000 spectrophotometer (Hach. Loveland. CO. USA). Total alkalinity and chloride were monitored using the titration method, and $\mathrm{pH}$ was monitored using an electronic $\mathrm{pH}$ meter ( $\mathrm{pH}$ pen. Fisher Scientific. Cincinnati. $\mathrm{OH}$. USA). Average of water quality parameters were: water temperature $22{ }^{\circ} \mathrm{C}$, dissolved oxygen $5.1 \mathrm{mg} / \mathrm{l}$, total ammonia $0.2 \mathrm{mg} / \mathrm{l}$, nitrite $0.05 \mathrm{mg} / \mathrm{l}$, total alkalinity $182 \mathrm{mg} / \mathrm{l}$, chlorides $550 \mathrm{mg}$ $/ \mathrm{I}$ and $\mathrm{pH}$ value was 7.6 all water quality parameters were within the acceptable levels for tilapia. At end of experiment the ovaries were removed and weighed for calculation of the GSI.

Table 1. Composition of the experimental diet for Nile tilapia (Oreochromis niloticus ) female fingerlings reared in glass aquaria.

\begin{tabular}{|l|l|}
\hline Ingredients & $\%$ \\
\hline Egg white & 28.5 \\
\hline Starch & 38.5 \\
\hline Mixture oil & 8 \\
\hline Cellulose & 20 \\
\hline Zinc-free mineral mix & 2 \\
\hline Vitamin mixture & 2 \\
\hline Carboxymethyl cellulose (CMC) & 1 \\
\hline Total & 100 \\
\hline
\end{tabular}

\begin{tabular}{|l|l|}
\hline Proximate analysis & $\%$ \\
\hline Moisture & 9.70 \\
\hline Protein & 25.23 \\
\hline Lipids & 8.27 \\
\hline Ash & 8.60 \\
\hline Fiber & 19.2 \\
\hline NFE & 28.00 \\
\hline Zinc (ppm) & 1.00 \\
\hline
\end{tabular}

\section{Growth response was calculated as a follows:}

Condition factor $(k)=100\left(W t / L^{3}\right)$. Where Wt is fish body weight $(\mathrm{g}) . \mathrm{L}$ is total length (cm), according to Hengsawat et al. (1997).

Weight gain ( $\mathrm{g}$ fish ) = mean final body weight - mean initial body weight

"Feed conversion ratio (FCR) was estimated according to Berger and Halver, (1987) as follow: Dry feed intake ( $\mathrm{gm}) /$ total weight gain $(\mathrm{gm})$.

Gonadosomatic index (GSI) was estimated as $=100$ (weight of gonads / total body weight). 
726 EFFECT OF DIFFERENT LEVELS OF ZINC ON GROWTH PERFORMANCE AND GONADOSOMATIC INDEX OF NILE TILAPIA (OREOCHROMIS NILOTICUS) FEMALES

\section{Statistical analysis:}

The data were analyzed by analysis of variance. Duncan's Multiple Range test was applied to final body weight, body length, condition factor, weight gain, daily weight gain, survival rate and gonadosomatic index. All statistics were carried out using Statistical analysis systems (SAS, 2004).

\section{RESULTS AND DISCUSSION}

\section{Growth performance of Oreochromis niloticus female fingerlings.}

Averages of final body weight was affected by different levels of zinc in Nile tilapia females as illustrated in Table (2) the mean final body weight in different treatments of Oreochromis niloticus females fed diets containing levels of zinc of 0.0, $10,25,50,75$ and $100 \mathrm{mg}$ of zinc / $\mathrm{kg}$ diet for 9 weeks were $37.40 \pm 1.0,37.58 \pm 1.02$, $45.27 \pm 1.33,45.90 \pm 1.33,40.67 \pm 0.86$ and $39.73 \pm 0.63$, respectively. Analysis of variance showed a significant difference between final body weight of Oreochromis niloticus females treated with $25 \mathrm{mg}$ zinc / $\mathrm{kg}$ diet and other treatments.

Final weight gain and daily weight gain of Nile tilapia (Oreochromis niloticus) females fed on the basal diet ( $2 \mathrm{mg} \mathrm{Zn} / \mathrm{kg}$ ) were significantly lower than those fed diets containing the different levels of zinc $(10-100 \mathrm{mg} \mathrm{Zn/} \mathrm{kg}$ diet). Weight gain and daily weight gain of Oreochromis niloticus females fed diets containing different levels of zinc $0.0,10,25,50,75$ and $100 \mathrm{mg} \mathrm{Zn} \mathrm{/} \mathrm{kg} \mathrm{diet} \mathrm{were} \mathrm{(10.14 \pm 0.06,}$ $12.28 \pm 0.06,19.11 \pm 0.006,16.00 \pm 0.057,13.80 \pm 0.05$ and $13.77 \pm 0.04)$ and $(0.13 \pm 0.0$, $0.16 \pm 0.0,0.24 \pm 0.003,0.21 \pm 0.003,0.18 \pm 0.0$ and $0.18 \pm 0.0$ ), respectively. The highest results were obtained from the level of $25 \mathrm{mg} \mathrm{Zn} \mathrm{/} \mathrm{kg} \mathrm{diet} \mathrm{followed} \mathrm{in} \mathrm{a}$ decreasing order by $50,75,100$ and $0.0 \mathrm{mg} \mathrm{Zn}$ (the control). Statistical analyses of weight gain and daily weight gain showed a significant difference between all treatments and the control group. The present results are in agreement with Satoh et al, (1987), Apines et al., (2001) and Ebrahim, (2005) they found significantly lower values with the control diets $(0.0 \mathrm{mg} \mathrm{Zn})$ when compared with those fed diets supplemented with different levels of zinc (Table 2).

Relative growth rate: As indicated in table (2) there were significant differences between level of $25 \mathrm{mg} \mathrm{Zn} / \mathrm{kg}$ diets and other treatments when Oreochromis niloticus females fed diets supplemented with different levels of zinc. The highest value was obtained from $25 \mathrm{mg} \mathrm{Zn} / \mathrm{kg}$ diet ( $73.42 \pm 3.86$ ) and lowest value was obtained by $0.0 \mathrm{mg} \mathrm{Zn/} \mathrm{kg}$ diet (37.31 1.67$)$ in relative growth rate.

Results of Table (2) illustrate the FCR values as affected by different levels of zinc $(0,10,25,50,75$ and $100 \mathrm{mg} \mathrm{Zn/kg} \mathrm{diet).} \mathrm{The} \mathrm{results} \mathrm{reveled} \mathrm{that} \mathrm{FCR} \mathrm{was}$ improved at level of $25 \mathrm{mg} \mathrm{Zn} \mathrm{/} \mathrm{kg} \mathrm{diet} \mathrm{than} \mathrm{other} \mathrm{treatments,} \mathrm{for} \mathrm{(Oreochromis}$ niloticus) females fingerlings. The results are in agreement with Ebrahim, (2005) who found that improve in FCR at level of $30 \mathrm{mg} \mathrm{Zn} \mathrm{/} \mathrm{kg} \mathrm{diets} \mathrm{than} \mathrm{all} \mathrm{other} \mathrm{treatments.}$ 
Table 2. Effect of different levels of zinc in diet on growth performance of female (Oreochromis niloticus) fingerlings females reared in glass aquaria.

\begin{tabular}{|c|c|c|c|c|c|c|c|c|}
\hline $\begin{array}{l}\text { Mg Zn / kg } \\
\text { diet }\end{array}$ & $\begin{array}{l}\text { Initial } \\
\text { weight. } \\
\text { (gm) }\end{array}$ & $\begin{array}{l}\text { Final } \\
\text { weight. } \\
\text { (gm) }\end{array}$ & $\begin{array}{l}\text { Final } \\
\text { length } \\
(\mathrm{cm})\end{array}$ & $\begin{array}{l}\text { K. } \\
\text { Factor }\end{array}$ & $\begin{array}{l}\text { Avg. } \\
\text { weight } \\
\text { gain }\end{array}$ & $\begin{array}{l}\text { Avg. } \\
\text { D.Wt. } \\
\text { gain }\end{array}$ & $\begin{array}{l}\text { RGR } \\
\%\end{array}$ & FCR \\
\hline 0.0 & 27.27 & $\begin{array}{l}37.40 \pm \\
1.01 \mathrm{~b} \\
\end{array}$ & $\begin{array}{l}13.33 \pm \\
0.16 c \\
\end{array}$ & $\begin{array}{l}1.58 \pm \\
0.02 a \\
\end{array}$ & $\begin{array}{l}10.14 \pm \\
0.06 \mathrm{e}\end{array}$ & $\begin{array}{l}0.13 \pm \\
0.0 \mathrm{e} \\
\end{array}$ & $\begin{array}{l}37.31 \pm \\
1.67 \mathrm{c} \\
\end{array}$ & $\begin{array}{l}6.190 \\
0.27 a \\
\end{array}$ \\
\hline 10 & 25.30 & $\begin{array}{l}37.58 \pm \\
1.02 \mathrm{~b} \\
\end{array}$ & $\begin{array}{l}13.50 \pm \\
0.11 \mathrm{cb} \\
\end{array}$ & $\begin{array}{l}1.53 \pm \\
0.04 a \\
\end{array}$ & $\begin{array}{l}12.28 \pm \\
0.06 d\end{array}$ & $\begin{array}{l}0.16 \pm \\
0.0 \mathrm{~d}\end{array}$ & $\begin{array}{l}48.70 \pm \\
1.89 \mathrm{~b}\end{array}$ & $\begin{array}{l}4.83 \pm \\
0.19 b c \\
\end{array}$ \\
\hline 25 & 26.17 & $\begin{array}{l}45.27 \pm \\
1.33 a \\
\end{array}$ & $\begin{array}{l}14.53 \pm \\
0.31 a \\
\end{array}$ & $\begin{array}{l}1.48 \pm \\
0.05 a \\
\end{array}$ & $\begin{array}{l}19.11 \pm \\
0.006 a\end{array}$ & $\begin{array}{l}0.24 \pm \\
0.003 a \\
\end{array}$ & $\begin{array}{l}73.42 \pm \\
3.86 a \\
\end{array}$ & $\begin{array}{l}3.43 \pm \\
0.16 \mathrm{~d} \\
\end{array}$ \\
\hline 50 & 29.90 & $\begin{array}{l}45.90 \pm \\
1.33 a\end{array}$ & $\begin{array}{l}14.23 \pm \\
0.20 \mathrm{ab}\end{array}$ & $\begin{array}{l}1.59 \pm \\
0.023 a\end{array}$ & $\begin{array}{l}16.00 \pm \\
0.057 \mathrm{~b} \\
\end{array}$ & $\begin{array}{l}0.21 \pm \\
0.003 \mathrm{~b}\end{array}$ & $\begin{array}{l}53.69 \pm \\
2.07 \mathrm{~b} \\
\end{array}$ & $\begin{array}{l}5.13 \pm \\
0.20 \mathrm{~b}\end{array}$ \\
\hline 75 & 26.87 & $\begin{array}{l}40.67 \pm \\
0.86 b\end{array}$ & $\begin{array}{l}14.10 \pm \\
0.23 a b\end{array}$ & $\begin{array}{l}1.45 \pm \\
0.04 a \\
\end{array}$ & $\begin{array}{l}13.80 \pm \\
0.05 c\end{array}$ & $\begin{array}{l}0.18 \pm \\
0.0 c\end{array}$ & $\begin{array}{l}51.46 \pm \\
1.36 \mathrm{~b} \\
\end{array}$ & $\begin{array}{l}4.78 \pm \\
0.04 b c\end{array}$ \\
\hline 100 & 25.97 & $\begin{array}{l}39.73 \pm \\
0.63 \mathrm{~b}\end{array}$ & $\begin{array}{l}13.57 \pm \\
0.24 c b\end{array}$ & $\begin{array}{l}1.59 \pm \\
0.05 a\end{array}$ & $\begin{array}{l}13.77 \pm \\
0.04 c\end{array}$ & $\begin{array}{l}0.18 \pm \\
0.0 \mathrm{C}\end{array}$ & $\begin{array}{l}53.10 \pm \\
1.55 b\end{array}$ & $\begin{array}{l}4.50 \pm \\
1.48 \mathrm{c}\end{array}$ \\
\hline
\end{tabular}

Means with the same letter in the same column are not significant differences at $(P<0.05)$.

Survival rate of females Oreochromis niloticus fingerlings ranged from $90-100$ $\%$. The results indicated that there were no significant differences among the tested dietary treatments, at the same time there were significant differences between them and those treated with (0.0.10 and $100 \mathrm{mg} \mathrm{Zn} / \mathrm{kg}$ diet). In the present study the survival rate at $25 \mathrm{mg} \mathrm{Zn} / \mathrm{kg}$ diets was the best result and more economical than other treatments. The results are in agreement with the results obtained by Eid and Ghonim, (1994) and Ebrahim, (2005) who reported that, high mortality has usually been associated with zinc deficiency in fish.

Gonadosomatic index (GSI) of Nile tilapia females fed on the diets on different levels of zinc are presented in table (3). It could be noticed that the gonadosomatic index for different levels of zinc concentration $(0.0,10,25,50,75$ and $100 \mathrm{mg} \mathrm{Zn} / \mathrm{kg}$ diet) were 1.44, 1.51, 1.82, 2.14, 1.89 and 1.95, respectively. The highest value of gonadosomatic index was obtained by level $50 \mathrm{mg} \mathrm{Zn} \mathrm{/} \mathrm{kg} \mathrm{diets.} \mathrm{Analysis} \mathrm{of} \mathrm{variarice}$ 
728 EFFECT OF DIFFERENT LEVELS OF ZINC ON GROWTH PERFORMANCE AND GONADOSOMATIC INDEX OF NILE TILAPIA (OREOCHROMIS NILOTICUS) FEMALES

showed no significant difference in GSI among fish treated with $(10,25,75$ and 100 $\mathrm{mg} \mathrm{Zn} \mathrm{/} \mathrm{kg}$ diet), at the same time there were significant difference between them and groups that treated with $50 \mathrm{mg}$ zinc / $\mathrm{kg}$ diet in the average of final gonadosomatic index of Oreochromis niloticus females.

The present results recommend adding $25 \mathrm{mg} \mathrm{Zn/} \mathrm{kg}$ diet to obtain the highest growth performance, survival rate and adding $50 \mathrm{mg} \mathrm{Zn} / \mathrm{kg}$ diet to obtain the highest gonadosomatic index.

Table 4. Effect of different dietary zinc levels on survival rate and gonadosomatic index of (Oreochromis niloticus) fingerlings females reared in glass aquaria.

\begin{tabular}{|c|c|c|c|c|c|}
\hline $\begin{array}{c}\text { Mg Zn/ kg } \\
\text { diet }\end{array}$ & $\begin{array}{c}\text { Initial } \\
\text { weight }\end{array}$ & Final weight & Survival rate & $\begin{array}{c}\text { Weight of } \\
\text { Gonads (g) }\end{array}$ & GSI \\
\hline 0.0 & 27.27 & $37.40 \pm 1.01 \mathrm{~b}$ & $90.00 \pm 0.0 \mathrm{~b}$ & $0.54 \pm 0.09 \mathrm{e}$ & $1.44 \pm 0.23 \mathrm{~b}$ \\
\hline 10 & 25.30 & $37.58 \pm 1.02 \mathrm{~b}$ & $90.00 \pm 0.0 \mathrm{~b}$ & $0.57 \pm 0.11 \mathrm{~d}$ & $1.51 \pm 0.26 \mathrm{ab}$ \\
\hline 25 & 26.17 & $45.27 \pm 1.33 \mathrm{a}$ & $100.00 \pm 0.0 \mathrm{a}$ & $0.83 \pm 0.08 \mathrm{a}$ & $1.83 \pm 0.13 \mathrm{ab}$ \\
\hline 50 & 29.90 & $45.90 \pm 1.33 \mathrm{a}$ & $100.00 \pm 0.0 \mathrm{a}$ & $0.99 \pm 0.107 \mathrm{~b}$ & $2.14 \pm 0.17 \mathrm{a}$ \\
\hline 75 & 26.87 & $40.67 \pm 0.86 \mathrm{~b}$ & $100.00 \pm 0.0 \mathrm{a}$ & $0.77 \pm 0.05 \mathrm{c}$ & $1.90 \pm 0.139 \mathrm{ab}$ \\
\hline 100 & 25.97 & $39.73 \pm 0.63 \mathrm{~b}$ & $90.00 \pm 0 \mathrm{~b}$ & $0.77 \pm 0.07 \mathrm{c}$ & $1.95 \pm 0.18 \mathrm{ab}$ \\
\hline
\end{tabular}

Means with the same letter in the same column are not significant differences at $(P<0.05)$.

\section{REFERENCES}

1. Apines, M. J., Satoh, S., Kiron, V., Watanabe, T., Nasu, N. and S. Fujita. 2001. Bioavailability of amino acids chelated and glass embeded zinc to rainbow trout oncarhynchus mykiss fingerlings. Aquaculture Nutr. 7: 221-228.

2. Berger, A. and J. E. Halver. 1987. Effect of dietary protein, lipid and carbohydrate content on the growth feed efficiency and carcass composition of striped bass, (Morone saxatities W.) fingerlings. Aquaculture, 18: 345-356.

3. Bettger, W. J. and B. L. O'Dell. 1981. A critical physiological role of zinc in the structure and function of biomembranes. Life Sci 28: 1425-1438.

4. Bray, TM. and W. J. Bettger. 1990. The physiological role of zinc as an antioxidant. Free Radic Biol Med 8: 281-291.

5. Cousins, R. J. 1996. Zinc. in: Brown. M.L. (Ed.). Present Knowledge in. Nutrition. $7^{\text {th }}$ ed International Life Sciences institute. Washington. DC. pp. 293-306.

6. Eid, A. and S. I. Ghonim. 1994. Dietary zinc requirement of fingerling Oreochromis niloticus. Aquaculture 119. 259-264. 
7. Gatın, D. M. and R. P. Wilson. 1983. Dietary zinc requirement of fingerling channel catfish. Journal of nutrition 113 (630-635).

8. Hayashi, K., H. Hara, P. Asvaarujanon. Y. Aoyama and P. Luangpituksa, 2001. Inggestion of insoluble dietary fibre increased zinc and iron absorption and restored growth rate and zinc absorption suppressed by dietary phytate in rats. $\mathrm{Br}$. J. Nutr. 86. 443-451.

9. Hengsawat, K., F. J. Ward and P. Jaruratjamorn. 1997. The effect of stocking density on yield, growth and mortality of African catfish (Clarias gariepinus Burchell 1822) cultured in cages Aquaculture 152: 67-76.

10. Hogstrand, C. and C. M. Wood. 1996. The physiology and toxicology of zinc in fish. In: Aquatic Toxicology. Edited by Taylor EW. Cambridge. UK: Cambridge Univ Press. p. 61-84.

11. Hogstrand, C., N. J. Gassman, B. Popova, C. M. Wood and P. J. Walsh. 1996. The physiology of massive zinc accumulation in the liver of female squirrelfish and its relationship to reproduction. J Exp Biol 199: 2543-2554.

12. Ebrahim, M. S. M. 2005. Fingerlings performance of Nile tilapia diets containing varying zinc levels. Egypt. J. Appl. Sci. 20 (3) 34-43.

13. McClain, W. R. and D. M. Gatlin. 1988. Dietary zinc requirement of Oreochromis. aureus and effects of dietary calcium and phytate on zinc bioavailability. Journal of the World Aquaculture Society 19: 103-108.

14. Ogino, C. and G. Y. Yang. 1978. Requirement of carp for dietary zinc. Bulletin of the Japanese, Society of Scientific Fishers 45: 967-969.

15. Satoh, S., T. Takeuchi and T. Watanabe. 1987. Availability to rainbow trout of zinc in white fish meal and of various zinc compounds. Nippon suisan Gakkaishi 53: 595-599.

16. SAS 2004. SAS/STAT Guide for Personal Computers, $6^{\text {th }}$ ed. Cary, NC. .

17. Stahl, J. L., M. E. Cook, M. L. Sunde and J. L. Greger. 1989. Enhanced humoral immunity in progeny chicks fed practical diets supplemented with zinc. Applied Agricultural Research 4:86-89.

18. Thompson, E. D., J. A. McDermott, T. B. Zerkle, J. A. Skare, B. L. B. Evans and D. B. Cody. 1989. Genotoxicity of zinc in 4 short-term mutagenicity says. Mutation Research 223:267-272.

19. Thompson, E. D., G. D. Mayer, P. J. Walsh and C. Hogstrand. 2002. Sexual maturation and reproductive zinc physiology in the female squirrelfish. Journal of Experimental Biology 205. 3367-3376 (2002).

20. Valee, B. L. and K. H. Falchuk. 1993. The biochemical basis of zinc physiology. Physiol. Rev. 73. 79-118. 
730 EFFECT OF DIFFERENT LEVELS OF ZINC ON GROWTH PERFORMANCE AND GONADOSOMATIC INDEX OF NILE TILAPIA (OREOCHROMIS NILOTICUS) FEMALES

تأثير مستويات مختلفة من الزتك على أداء النمو ودليل المناسل لإناث البلطي اللنيلي المرباه في أحواض زجاجية

$$
\text { أحمد مصطفى خاطر }
$$

المعل المركزي لبحوث الثروة السككية بالعباسة - مركز البحوث الزراعية - وزارة الزراعة. -

$$
\text { الدقي - الجبزة المعزي }
$$

أجريت هذه اللراسة بالمعل المركزي لبحوث الثزوة السمكية بالعباسة أبوحماد شرقية.

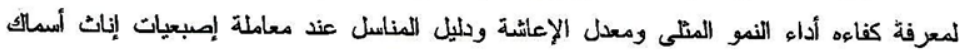

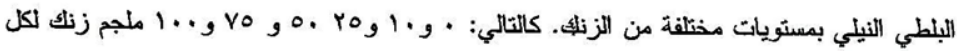

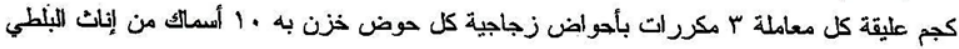
- النيلي دلت النتائج على وجود اختلافات معنوية في أداء النمو، متوسط الوزن اللنهائي ، والوزن المكتسب

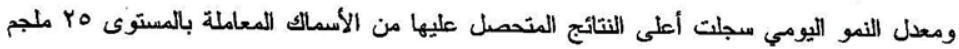

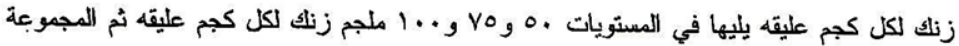

الضعابطة.

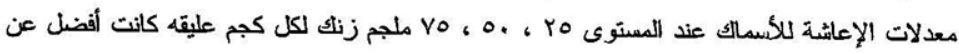

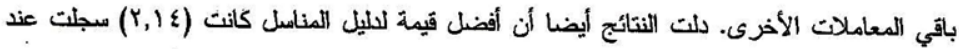

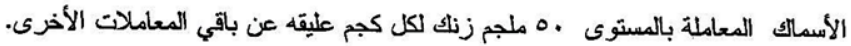

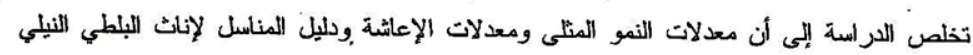
كانت عند المستوى 0Y ملجم زنأك لكل كجم عليقه. 